\title{
PROJECTIVE APPROACH TO THE SOCIAL ADAPTABILITY RESEARCH
}

\author{
Yuliia Madinova \\ PhD in Psychology, Senior Teacher of the Department of Graphic Design \\ Kyiv National University of Culture and Arts \\ 36, Konovaltsia Str., Kyiv, Ukraine, 01133 \\ madinova@gmail.com, https://orcid.org/0000-0003-4899-8378
}

\begin{abstract}
Purpose: the article is devoted to theoretical research and proof of social adaptability existence as a personality property, its connection with adaptation and disadaptation, its research from the point of psychological approach, as well as empirical ways of searching quick recognition of adaptive ability decrease of young organism and psyche. Objectives: 1) to research theoretical approaches to social adaptability existence as a personality property, its connection with adaptation and disadaptation, 2) to explore scientific views on adaptability within the integrity paradigm, 3) to show emirically options to study adaptability using projective methods. Methods: theoretical methods were used, such as average qualitative indicators analysis, correlation analysis, namely, quantitative and qualitative analysis of adaptability indicators and projective methodology markers. Results: theoretical analysis of different approaches to personality social adaptability and its links to adaptation and disadaptation was carried out. As a diagnostic tool, projective diagnostic methods were used, which allowed to quickly reflect the level and social adaptability indicators of the firstyear student. Average values of general social adaptability were researched and their correlation with other adaptation disorders markers was confirmed. Quantitative and qualitative analysis between adaptability indicators and projective markers was performed. As a conclusion, we built up a model of fifteen factors, this research indicated that the predominance of some bright colours in the drawings corresponds to general adaptation increasing, orientation in society and reducing depression, as well as increasing emotionality. In its turn, the presence of monochrome colours shows an emotional increase and the state of health decrease. If a person uses hatching in drawings, this indicates a rigidity decrease. Some compositional figures highlight an increase in general adaptation and accuracy of social expectations orientation. The presence of such compositional principles like center, rhythm and proportions in the figures indicate an increase in general adaptation and satisfaction and decrease in disadaptation and depression. Conclusions: according to the research, we identified the role of social adaptability of a young person, investigated the phenomenon of adaptability using theoretical methods, and practically performed an experiment, using a projective technique.
\end{abstract}

Keywords: adaptation, disadaptation, projective technique, geometric composition, social adaptability.

\section{Introduction}

Finding ways of keeping and promoting human health is one of the most pressing problems nowadays, which requires an integrated approach. This is especially true over the previous year, when people were forced to change their usual rhythm, adapting to the restrictions and new rules of work and life. One of the important criteria of health is the ability of the psyche and the human 
body to adapt, as adaptation is expressed in interaction with the environment and indicates the risk of developing diseases.

The question of human adaptation has always been an actual subject of consideration in various fields of knowledge: biology, philosophy, sociology, psychology, ethics, etc., which, in turn, gave rise to the terminology polysemanticity related to the human adaptation problem. (Суханов, 2011)

The first time, the concept of "adaptation" (from Latin word "adaptation") appeared in biology in the 18th century and meant adaptation to a changing environment. Very quickly, this concept went beyond the limits of biology and acquired the status of a general science term, since it characterized the phenomena and processes studied in other fields of science and, accordingly, studied by various branches of knowledge. Today, adaptation is one of the fundamental and universal properties of any biosystem (Казначеев, 1986). Thus, adaptation is considered as:

1) as a process of adapting of the object to constantly changing conditions of an external or internal environment;

2) as a result of this adaptation process - maintaining the stability of the object in changing conditions;

3) as a property of the system, that is, its ability to an effective process of adaptation, which received a separate name - "adaptability" (Оношко, 2009).

In psychology, personal adaptation is considered in several aspects - mental, social, physiological and psychological.

F.B. Berezin understands mental adaptation as "the process of becoming the optimal correspondence between the person and the environment during the performance of human activity, which allows the individual to meet current needs and realize significant goals associated with them, while keeping mental and physical health" (Березин, 1988: 67).

A complex research of all aspects of mental adaptation provides, in his opinion, the study of the mental sphere, microsocial interaction, the functioning of cerebral mechanisms and related vegetative-humoral characteristics. Having discovered the connection between the adaptation process and homeostasis and the fact that mental homeostasis can be estimated as a state in which the entire system of primary and acquired needs is satisfied, F.B. Berezin comes to a conclution that "mental adaptation" should include needs, since mental adaptation can be considered effective if excessive tension of adaptation mechanisms leads to disruption of the normal functioning of the body and to disruption of physical (or mental) health (Березин, 1988).

He identifies the main factors affecting the success of mental adaptation: stress, anxiety, frustration, behavior integration, the communicative sphere and the system of humoral regulation. He highlights a kind of behavior integration - intropsychic conflict - the incompatibility and collision of conflicting personality relations, which deeply complicate the whole construction of integrated behavior, which, in turn, leads to an increase in frustration tension and an increase in the risk of mental adaptation disorders.

Researching the influence on the adaptation process of a microsocial environment in which a person's daily activities take place and with which his relationships and interests are most closely related, F.B. Berezin comes to a conclusion that it is necessary to consider socio-psychological adaptation as an independent aspect of mental adaptation along with mental and psychophysiological ones (Березин, 1988).

The effectiveness of mental adaptation, the author believes, cannot be considered without physiological shifts, which entail its mechanisms tension, maintaining effectiveness with 
inconsistency in the system "person - environment" or the appearance of mental adaptation disorder, so he underlines psychophysiological adaptation as an integral and relatively independent aspect of mental adaptation in a broad sense. The tension of the mental adaptation process leads to a number of somatic shifts due to the implementation of hypothalamic influences through nerve pathways, the system of releasing factors and tropnous hormones of the pituitary gland, through changes in vegetative-humoral regulation (Березин, 1988).

The psychophysiological adaptation structure involves: firstly, hypothalamic structures, secondly, additional levels of regulation (in particular, peripheral mechanisms of vegetativehumoral regulation and the level of the organ or executive system), which ensure the relative independence of psychophysiological adaptation and its inverse effect on mental adaptation itself through integration cerebral mechanisms (Березин, 1988) A.O. Rean proposes a conceptual adaptation scheme, which consists of three main components: 1) adaptation as a result is characterized by a degree of adaptability; 2) as a process it is characterized by space and temporal mechanisms; 3) as a source of neoplasms - a complex of actively formed qualities. In the sociopsychological adaptation of the personality, A.O. Rean identifies a new factor - the developed socio-psychological tolerance of the personality, which effectively works with certain inconsistencies between the positions of the personality and the prevailing demands of the environment. Developed socio-psychological tolerance prevents the development of cognitive dissonance, and therefore personality disadaptation (Реан, 2006: 94).

The work of T.V. Sereda (Реaн, 2006: 14) provides the research of the definition of "adaptation", which includes 46 definitions that are partially scientific and change in the process of scientific knowledge development.

Thus, nowadays, the basic concepts and terms of adaptology are a bit differentiated and require clarification of interpretations regarding the specific research situation (Оношко, 2009), (Seitova, 2021).

The process of human adaptation is distinguished by adaptogenic factors participation of different nature in it: biological, psychological and social. The biological adaptation of a person to constantly changing environmental conditions is mediated by psychological, and they, in turn, by social factors on the principle of "matryoshka", which is initially formed in direct order: biological, psychological, social, and then in the "opposite" direction - already in the process of system functioning. At the human level, according to the nature of his whole life, biological adaptation turns into socio-psycho-biological. Structural-functional connections of human organism with nature are supplemented by individual structural-functional organization of his personality and structural-functional connections of human organism with social environment.

Psychological adaptation opportunities of the person (his psychological adaptation) due to the middle situation in personal adaptation both bio-psycho-socio-systems can become both the compensator, and a decompensator between bio- and socio-components. At impact on the person external or internal biological the adapto-genetic factors the level of psychological adaptation of his personality either is capable to compensate these actions and not to break social components of the person adaptation, or not. Then the person can give this deadapting influence on higher level of the system organization, which adapts - sociological, and sometimes to strengthen it. The same principle of person adaptation process (it is obligatory through psychological level) is observed at social adapto-genes influence too.

Psychological characteristics of adaptation are divided into dynamic (characterizing the adaptation process), static (characterizing the adaptation result) and subjective (characterizing the 
adaptive potency of the personality) "the adaptability of the personality" belongs to such characteristics.

In the researches devoted to an adaptation problem - similar terms "adaptive system" and "personaliy adaptation potential" are also used. M.V. Romm calls adaptive such system, which has potential for purposeful (active or reactive) transformations of the structure according to the requirement, based on use of information feedback mechanism (Ромм, 2002).

The difference and diversity of interpretations of the phenomenon of adaptability indicate both the difference in the theoretical and methodological approaches in the research basis, as well as the multinature, multiaspects of this phenomenon itself and the need for its further research.

Analysis of scientific literature on the topic of research demonstrates various approaches to the adaptability research phenomenon: natural scientific, psychological, philosophical (Мадінова, 2016). These authors distinguish two trends in the adaptability research: evolutionary and individually-personal. From the point of an individual-personal approach, adaptability is interpreted both as a personal property that determines a person's ability to adapt, and as a level of his adaptability to a given environment (as a result, the concept of "adaptivity" is often replaced by the concept of "adaptability", which expresses the effectiveness of the adaptation process).

In psychology, adaptive qualities are interpreted traditionally in the context of personality traits or in the context of effective behavior and skills. The enormous amounts of empirical data, accumulated by this time, do not allow us to come to any certain conclusion regarding the composition of qualities that can be interpreted as adaptive (Мельникова, 2006). The information mosaic and the large variability of the categorical-conceptual apparatus of adaptology is understandable, taking into account two factors:

1) the diversity of approaches and the absence of a single concept capable of covering the maximum number of aspects of such a complex object (as well as most psychomeric objects); 2) relativity of adaptive qualities (the concept was introduced by Ch. Darwin): devices, useful in some conditions, become useless or even harmful in other conditions (Мельникова, 2006). The last one is especially evident in researches that compare the individual psychological characteristics of high and low-adaptated groups, in which "the subject adaptation plan factors are studied mostly "analytically" - and their autonomous effects, and not as a certain whole structure. But different adaptation factors do not act independently from each other, giving a certain summurising effect, but form a certain structure with complex relationships. Some of them can strengthen or, viseversa, weaken the influence of others" (Мельникова, 2006: 94-97). It is possible to overcome this obstacle, when considering the person adaptive properties from the position of their integral integrity.

I.V. Ershova-Babenko studies the mental processes from the point of view of integrity. The psyche of a person acts as a synergistic object, a system of synergistic order within the framework of a new scientific discipline - psychosinergetics (Ершова-Бабенко, 2012). From the position of the author of psychosynergetics, the psyche is "in fact these are hypersystems of the synergistic order, in which three phases are distinguished during the period of the body life (from conception to death): ante-surviving (before conception), lifetime (corresponds to the concept of "mental reality system" accepted in psychology)" and post-life (post-mortal) phases. This refers to the polymodal dynamic multilevel and multidimensional integrity of both the hypersystem itself and each of its phases (Бабенко, 2012).

The purpose our work is to research social adaptability as a personality property, its connection with adaptation and disadaptation, to find empirical ways of search of quick recognition 
of decrease of adaptive abilities of young organism and psyche. Objectives: 1) to research theoretically approaches to of social adaptability existence as a personality property of personality, its connection with adaptation and disadaptation; 2) to explore scientist's views on adaptability within the integrity paradigm; 3) to show emirically options for studying adaptability using projective methods.

\section{Research methods}

Inquiring for the first time about the mental structure composition of a person as a whole, the intrapsychic world of personality back in the 90s (Ершова-Бабенко, 1992) and having developed the conceptual model "whole-in-whole" and the method "Creating force" at the beginning of "2000" (Ершова-Бабенко, 2005), I.V. Ershova-Babenko developed on this basis the projective methodology "10x10" (10 drawings in 10 minutes) (Ершова-Бабенко, 2013), based on the principles, laws of geometric composition in the field of applied art (Бабенко, 2013), the composition is understood as a process of construction - based on compositional principles and using compositional features.

A characteristic feature of compositional construction is that it always develops within certain limits, implies the presence of parts connected to each other by a system of relations" (Никифоров, 2003). The position of interpretation of the composition of one drawing as a whole, included in the image of 10 drawings, allows to distinguish the macro composition. That is, all 10 drawings that are used in the methodology should be considered as one picture. We can analyze it in this way (the author believes), because it is a mosaic of the inner world of a person. On the other hand, the microcomposition is the composition of each frame, that is, each of the ten figures. "And this recognition of compositivity in the organization of a person's mental space and time allows us to diagnose, looking at the drawings that he creates" (Бабенко, 2013: 10).

As part of a dissertation research of the disadaptation phenomenon, conducted on the basis of Odessa National Medical University among students of primary specialization, totally 390 respondents, one of the investigated tasks was to study the characteristics of personality adaptability. In particular, to diagnose the general disadaptation of personality, we used the projective technique "10x10", and to diagnose the level of social adaptability of personality - the original "Test Questionnaire of Social Adaptability" by A.P. Sannikova, A.V. Kuznetsova.

This technique identifies a complex of formally dynamic and qualitative indicators of adaptability:

1) the indicator of the wide coverage of social signals in an actual adaptation situation (WCSC), characterizes the wide field of perception degree by a person of a new or unexpected social situations;

2) the indicator of the easy recognition and hierarchization of social signals (ERSC), related to the estimation of the social situation, its understanding, on which depends the adequacy of the personality's behavioral reaction;

3) the indicator of accuracy orientation in social expectations (AOCE), reflects the quality provided in the understanding and estimation by the person of the requirements and expectations of the social environment in mutual interaction, in the ability to predict changes in the people's moods and behavior, to predict the result of interaction with them;

4) the indicator of emotional experience stability (EES), the tendency of a person to maintain an emotional experience arising as a reaction to a new or unexpected situation, and hold it for a long time without significant changes in the characteristics of dominant emotions; 
5) the indicator of readiness to change ( $\mathrm{RCh}$ ), reflecting the degree of the person's openness to the new experience;

6) the indicator of readiness to implement constructive actions in order to overcome failures (ROF), the readiness of the personality to influence the development of events actively in a new and changing situation;

7) the indicator of readiness for the implementation of actions for achieving the goal (RAG), characterizes the ability of the personality to behave effectively and productively in an adaptive social situation, the personality tendency to act actively in the implementation of significant goals, taking into account changes taking place in the situation, as well as in conditions of uncertainty of events;

8) the indicator of general personal satisfaction (GPS), diagnoses personality adaptability (Санникова, 2009; Sannikova, Sannikov \& Husak, 2020).

We selected the additional diagnostic tools, such as the test questionnaire of psychophysiological disadaptation of A.M. Rodina, which is an integral part of the whole approach in the study of personality adaptation/disadaptation. The method allows you to recognize the signs of personality's psychophysiological disadaptation: health deterioration, emotional shifts (ESh), features of individual mental processes (FIMP), decrease in general activity (DGA), feeling of fatigue (FF); somatic-vegetative disorders (SVD), "sleep/wake up" cycle disorders (SWD); characteristics of social interaction (CSI); reduced motivation for activity (RMA).

\section{Results and discussions}

Received as a result of study of social adaptivity methology, the average integral indicators of the adaptability of the studied sample of medical students are detected at different levels (Figure 1).

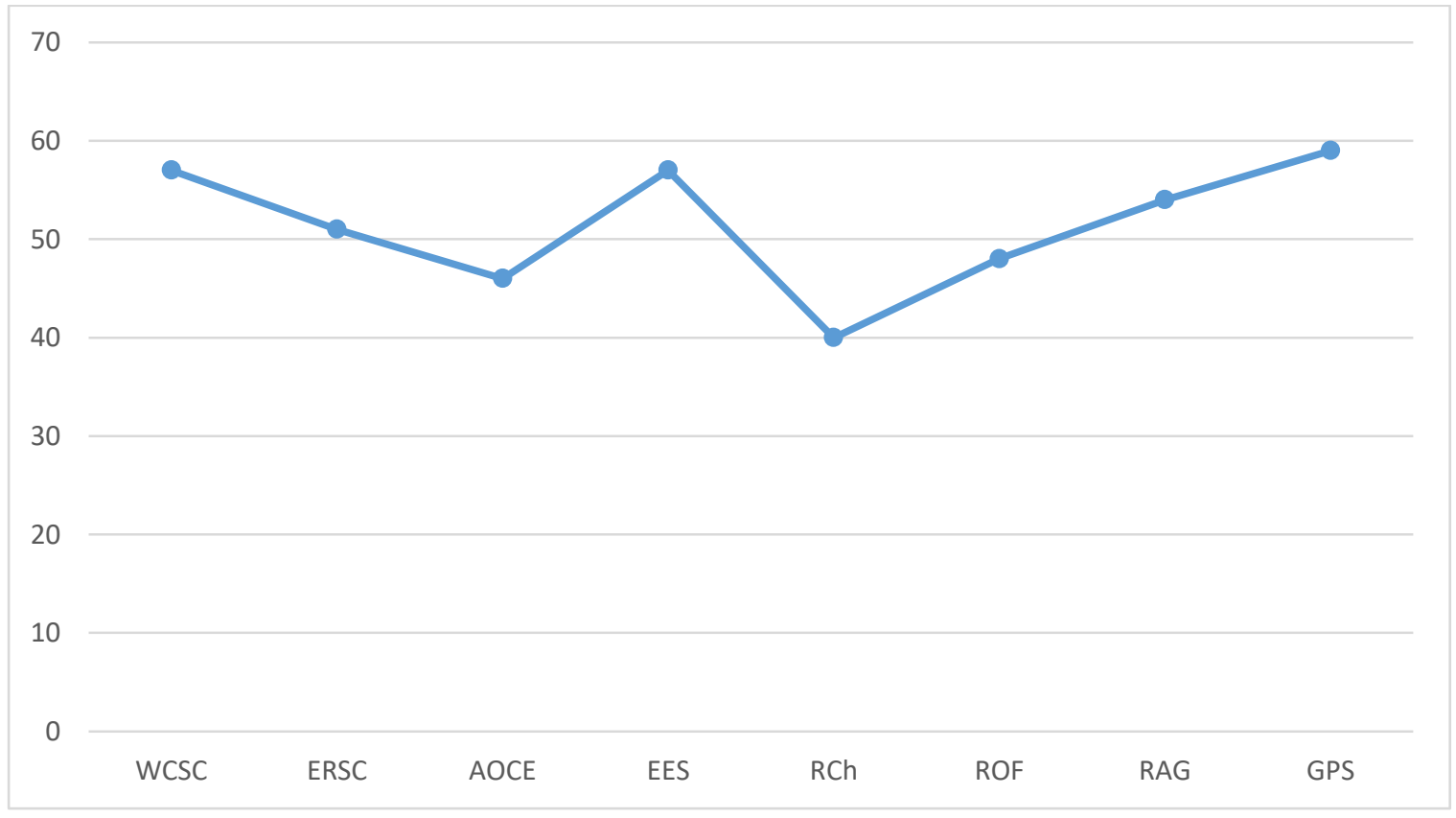

Figure 1. Average indicators of social adaptability

Moreover, adaptability indicators have different poles of attraction: 1) an indicator of the wide coverage of social signals (WCSS), indicator of easy recognition and hierarchization of social 
signals (ERSS), indicator of emotional experience stability (EES), Readiness for Action for Achieving Goal (RAAG) indicator tends to increase, which indicates the understanding, desire and possible readiness of the personality to act in social situations, as well as to achieve their goals, while maintaining a normal emotional background; 2) the indicator of general personal satisfaction (GPS), which is the indicator of general adaptability, confirms a moderate level of general satisfaction; 3 ) the indicator of accuracy orientation in social expectations (AOSE) and the indicator of readiness to carry out constructive actions for overcoming failures (ROF) indicate a lack of understanding of the social situation by the person, and, accordingly, readiness to carry out active actions to influence the situation; 4) the indicator of readiness to change (RCh) is the smallest of the indicators of adaptability, which indicates that the personality is not ready for a new experience.

The total social adaptability according to the research of TSA $=47.41 \% \pm 3.17$ - falls into the second quarter, which characterizes the parameter below the average level of adaptability development.

The methodology of studying psychophysiological disadaptation by A.M. Rodina showed that in the phenomenon structure, which was researched, we saw opposite poles signs. The parameter, characterizing decrease in the general activity (DGA.3), is expressed at highest possible level, indicator of decrease in motivation to activity (DMA) is expressed as well, the parameter, indicating violation of the "sleep/wake up" cycle (SWC), is expressed below than average.

The rest of disadaptation indicators - health deterioration, somatic - vegetative disorders, characteristics of social interaction express a moderate level (Figure 2).

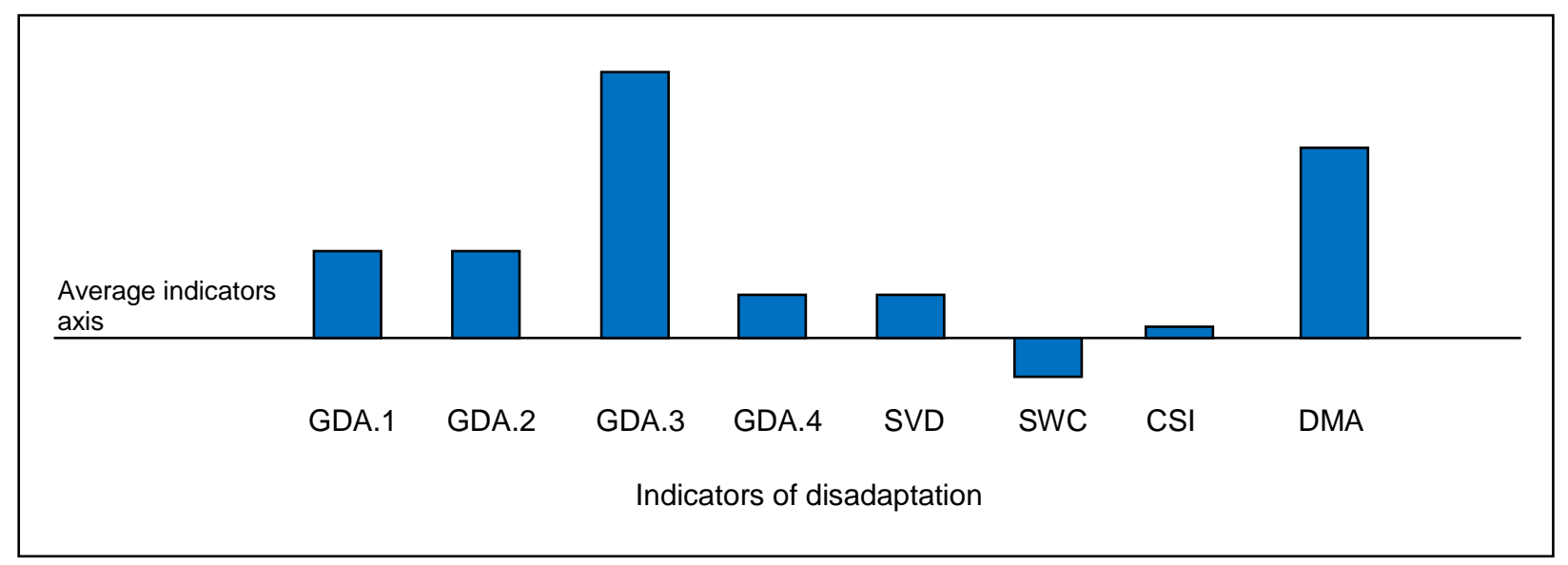

Figure 2. Average indicators of desadaptation

The results show that there are separate signs of psychophysiological disadaptation in the researched people. It can be seen in worse level of health, which is the result of somatic-vegetative disorders, emotional instability, hysterics, fatigue, as well as unwillingness and refusal to act.

In order to identify the possibility of diagnosing the adaptability of the medical student's personality and its forms during the period of primary professionalization, we conducted a correlation analysis of the relationship between the individual-psychological characteristics of the personality and the characteristics of the drawings of the studied students.

Correlation analysis underlined the following relationships of drawing figures and indicators of disadaptation - there are positive and negative correlations of high level of significance $(\rho \leq 0.01)$ (Table 1). 
Table 1

Value of correlation coefficients between pictures indicators and adaptation indicators

\begin{tabular}{|c|c|c|c|c|c|c|c|c|c|c|c|}
\hline & & \multicolumn{10}{|c|}{ Adaptation indicators } \\
\hline & & AOSE & EES & ROF & GPS & GPA & GDA.1 & GDA.3 & SVD & CSI & RMA \\
\hline \multirow{9}{*}{ 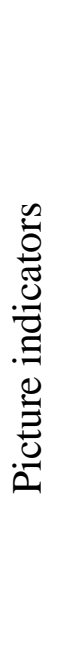 } & Or & & $-122 * *$ & & & & & & & & \\
\hline & $\mathrm{YC}$ & & & & $123 * *$ & & & & & $-99 * *$ & \\
\hline & $\mathrm{RC}$ & & & & & & & & & $-115^{* *}$ & $-122 * *$ \\
\hline & $\mathrm{VC}$ & $-104 * *$ & $-100 * *$ & & & & & & & & \\
\hline & $\mathrm{BC}$ & $115^{* *}$ & & & & & & & & & \\
\hline & $\mathrm{GC}$ & & & & & & & $117 * *$ & & & \\
\hline & $\mathrm{D}$ & & & & & $117 * *$ & $122 * *$ & $129 * *$ & $111 * *$ & & \\
\hline & $\mathrm{C}$ & & & $110 * *$ & & & & & & & \\
\hline & DSh & $-121^{* *}$ & & & & & & & & & \\
\hline
\end{tabular}

Note: 1) zeros and comas are not indicated; 2) ** $-\mathrm{c} \leq 0.01$. GPA - general psychophysiological disadaptation; GDA.1 - decrease in the general activity: emotional shifts; GDA.3 - decrease in the general activity: decrease of general activity; SVD - somatic-vegetative disorders; CSI - characteristics of social interaction; RMA - reduced motivation for activity; AOSE - accuracy orientation in social expectations; EES - emotional experience stability; ROF readiness to implement constructive actions in order to overcome failures; GPS is a general personal satisfaction. D - dynamics, C - contrast; DSh - diagonal shape; RC - raspberry colour; VC - violet colour; BC - colour black; GC - grey colour; YC - yellow colour; Or - orientation.

The presence of black colour in the drawings shows the personality's ability to navigate the situation, while purple indicates a decrease in this quality; yellow color positively correlates with the indicator of general satisfaction, and along with raspberry colour indicates a decrease in negative manifestations of interaction in society; raspberry colour also serves as the indicator of increased motivation for activity.

Dynamic drawings underline a number of disadaptation indicators, such as personality health deterioration, mental processes, somato-vegetative disorders and general personal disadaptation; the presence of contrasting drawings and their construction into a compositional diagonal figure may indicate the person's readiness to perform actions for achieving the goal (Picture 1).

Analysis showed that the predominance of blue, yellow and green colours in the drawings contributes to an increase in general adaptation, orientation in society and a depression decrease. In turn, the presence of gray and black colours indicates an increase in emotionality and health deterioration. Red and raspberry colours indicate emotionality and disadaptation. 


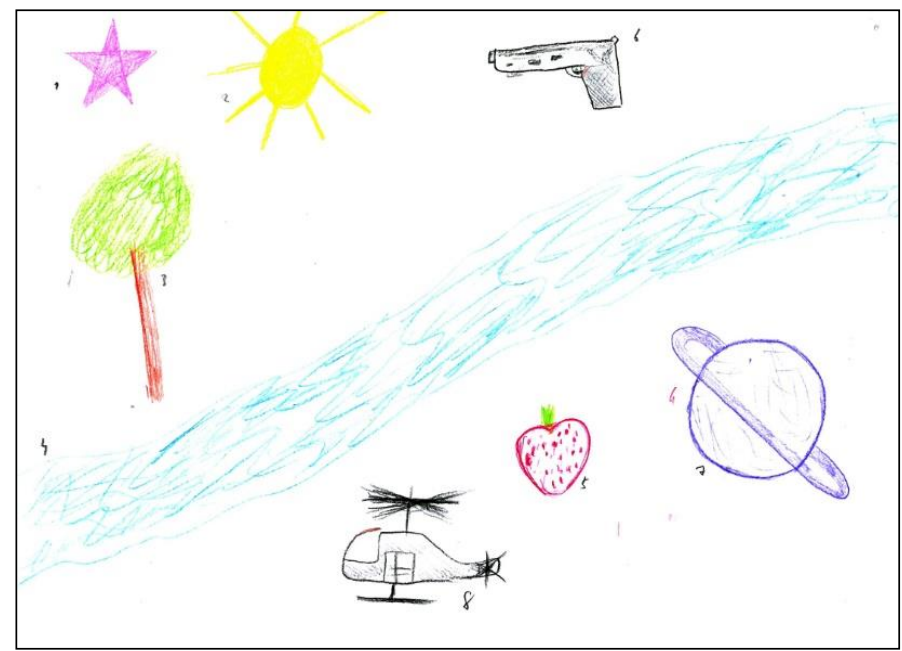

Picture 1. Diagonal in the picture

With an increase in hatching, rigidity decreases. Stable forms of the composition (rectangle, diagonal) indicate an increase in general adaptation and accuracy orientation in social expectations, and unstable (oval) - a health deterioration and a decrease in motivation. Compositions such as center, rhythm, and proportions indicate an increase in general adaptation and satisfaction, reduced disadaptation and depression. Drawings, using deviation from scale indicate possible manifestations of paranoia and a decrease in readiness for changing social environment (Picture 2).

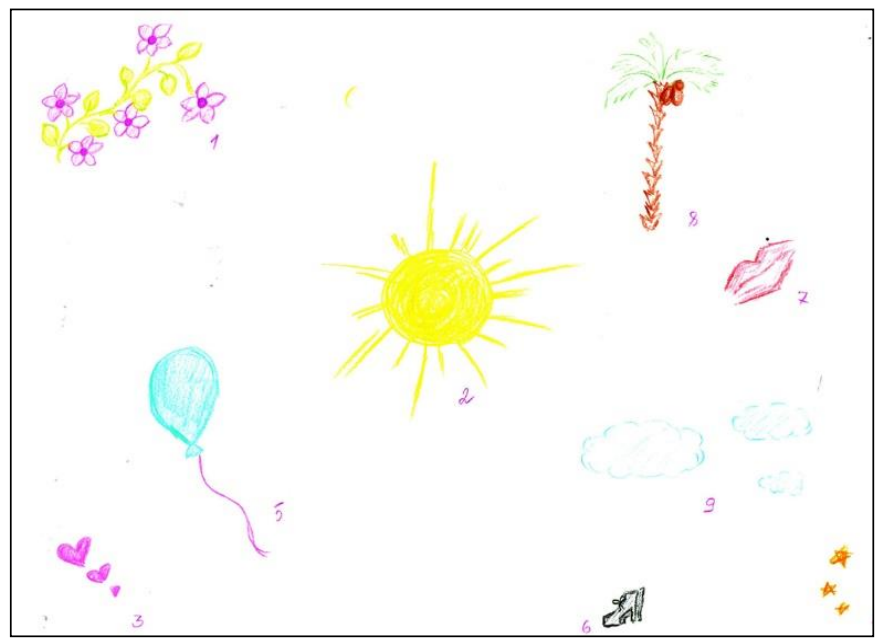

Picture 2. Center in the figure

\section{Conclusions}

In this research, we updated the role of personality social adaptability, theoretically investigated and practically proved this phenomenon on the example of primary professionalization students, highlighted the understanding of the human psyche from the point of integrity within the framework of the psychosynergetic approach as a compositional system, which made it possible to emphasize the importance of studying indicators of adaptability.

Based on this approach, we considered projective diagnostic methods, carried out an analysis of adaptability indicators using the 10x10 projective technique, which is based on geometric composition methods. As a result, we have identified the links between the markers of the projective methodology and social adaptability indicators, such as the use of various colours, forms, objects centering, rhythm, proportions, scaling, dynamics in the drawings. 
Prospects for further research: this research showed the great potential of projective techniques in diagnosing mental phenomena, which suggests their relationship and the feasibility of research in the future.

\section{Literature}

1. Бабенко, В.П. (2013). Беседа о композищии с кинооператором В.П. Бабенко, членом Союза кинематографистов СССР и Украины. Одесса : Гринь.

2. Березин, Ф.Б. (1988). Психическая и психофизиологическая адаптация человека. Ленинград : Наука.

3. Ершова-Бабенко, И.В., \& Мадинова, Ю.И. (2013). Инновационный диагностический и коррекционный инструмент для психологов: симптомокомплекс композиционной организации рисунка, Материаль ІІІ Международной научно-практической конференции «Инновачии и современные технологии в системе образования» (г. Прага, 20-21 февраля 2013 г.). (с. 204-206). Прага : Sociosfüra-CZ.

4. Ершова-Бабенко, И.В. (1992). Методология исследования психики как синергетического объекта. (Монография). Одесса : ОДЭКОМ.

5. Ершова-Бабенко, И.В. (2005). Психосинергетические стратегии человеческой деятельности. (Концептуальная модель). (Монография). Винница : NOVA RNYHA.

6. Казначеев, В.П. (1986). Адаптация и конституция человека. Новосибирск : Наука.

7. Мадінова, Ю.І. (2016). Особливості дезаптації студентів-медиків. (Дис. канд. психол. наук). Одеса.

8. Мельникова, Н.Н. (2006). Адаптивные свойства личности: проблемы изучения, Материаль межвузовской научно-практической конференции «Сочиальная психология сегодня: наука и практика» (2. Санкт-Петербург, 15 июня 2006 г.). Санкт-Петербург : СПбГУП.

9. Никифоров, Г.С. (2003). Практикум по психологии менеджмента и профессиональной деятельности. Санкт-Петербург : СПбГУП.

10. Оношко, Е.С. (2009). Понятийное ядро теории адаптаџии: терминологический аспект. Кемерово : Вестник КемГУ.

11. Реан, А.А. (2006). Психология адаптащии личности. Анализ. Теория. Практика. (Монография). Санкт-Петербург : Прайм-ЕВРО-знак.

12. Ромм, М.В. (2002). Адаптация личности в соииуме. Теоретико-методологический аспект. (Монография). Новосибирск : Наука.

13. Санникова, О.П. (2009). Адаптивность личности. (Монография). Одесса: Изд. Н.П. Черкассов.

14. Суханов, А.А. (2011). Анализ понимания адаптащии человека в отечественных психологических исследованиях. Москва : Гуманитарный вектор.

15. Rean, A.A., \& Konovalov, I.A. (2020). Indicators of Parent-Child Relationships in the Context of Various Socio-Demographic Parameters. Интеграџия образования. Integration of Education, 24(3), 433-452. doi: https://doi.org/10.15507/1991-9468.100.024.202003.433-452

16. Sannikova, O., Sannikov, O., \& Husak, L. (2020). Features of deciveness in individuals with different emotional disposition. Georgian Med News, 301, 136-142. Retrieved from https://pubmed.ncbi.nlm.nih.gov/32535578/

17. Seitova, A., Belov, G., Muratov, Z., Murzalieva, A., Abdullaeva, Z., Zhanbaeva, A., et al. (2021). Physiological, Anatomical, Psychological and Cultural-Ethnic Aspects of Indian Students Adaptation during Study in Kyrgyzstan Medical Universities. Open Journal of Medical Psychology, 10(1). https://DOI.org/10.4236/ojmp.2021.101001 


\section{References}

1. Babenko, V.P. (2013). Beseda o kompozicii s kinooperatorom V.P. Babenko, chlenom Sojuza kinematografistov SSSR $i$ Ukrainy [Conversation about composition with the cameraman V.P. Babenko, the member of the Cinematographers Union of the USSR and Ukraine]. Odessa : Grin [in Russian].

2. Berezin, F.B. (1988). Psihicheskaja i psihofiziologicheskaja adaptacija cheloveka [Mental and psychophysiological adaptation of a person]. Leningrad : Nauka [in Russian].

3. Ershova-Babenko, I.V., Madinova Y.I. (2013). Innovacionnyj diagnosticheskij i korrekcionnyj instrument dlja psihologov: simptomokompleks kompozicionnoj organizacii risunka [The innovative diagnostic and correctional tool for psychologists: Symptomo-complex of the composite organization of the picture], Proceedings from Mezhdunarodnaya nauchnoprakticheskaya konferentsiya "Innovatsii i sovremennyie tehnologii v sisteme obrazovaniya" International Scientific and Practical Conference "Innovations and Modern Technologies in Education” (Prague, February 20-21th, 2013). (pp. 204-206). Prague : Sociosféra-CZ [in Russian].

4. Ershova-Babenko, I.V. (1992). Metodologija issledovanija psihiki kak sinergeticheskogo objekta [Methodology of mentality research as synergetic object]. Odessa : ODEKOM [in Russian].

5. Ershova-Babenko, I.V. (2005). Psihosinergeticheskie strategii chelovecheskoj dejatel'nosti. (Konceptual'naja model') [Psycho-synergetic strategies of human activity. (Conceptual model)]. Odessa: NOVA KNYHA [in Russian].

6. Kaznacheev, V.P. (1986). Adaptacija $i$ konstitucija cheloveka [Human adaptation and constitution]. Novosibirsk : Nauka [in Russian].

7. Madinova, Y.I. (2016). Osoblyvosti dezaptatsii studentiv-medykiv. [Particular qualities of disadaptation of students]. Candidate's thesis. Odesa [in Ukrainian].

8. Melnikova, N.N. (2006). Adaptivnye svojstva lichnosti: problemy izuchenija [Adaptive traits of personality: problems of study], Proceedings from Materialy mezhvuzovskoj nauchnoprakticheskoj konferencii «Social'naja psihologija segodnja: nauka i praktika»-Materials of the International Scientific and Practical Conference "Social psychology today: science and practice” (St. Petersburg, June 15 ${ }^{\text {th }}$, 2006). Saint Petersburg : SPbGUP [in Russian].

9. Nikiforov, G.S. (2003). Praktikum po psihologii menedzhmenta i professional'noj dejatel'nosti [Workshop on psychology of the management and professional activeness]. Saint Petersburg: SPbGUP [in Russian].

10. Onoshko, E.S. (2009). Ponjatijnoe jadro teorii adaptacii: terminologicheskij aspekt [Conceptual issues of adaptation theory: terminological aspect]. Kemerovo : Vestnik KemGU [in Russian].

11. Rean, A.A. (2006). Psihologija adaptacii lichnosti. Analiz. Teorija. Praktika [Psychology of personality adaptation. Analysis. Theory. Practice]. Saint Petersburg : Prajm-EVRO-znak [in Russian].

12. Romm, M.V. (2002). Adaptacija lichnosti v sociume. Teoretiko-metodologicheskij aspekt [Personal adaptation in society. Theoretical and methodological aspects]. Novosibirsk : Nauka [in Russian].

13. Sannikova, O.P. (2009). Adaptivnost' lichnosti [Adaptability of person]. Odessa : Izd. N.P. Cherkassov [in Russian].

14. Suhanov, A.A. (2011). Analiz ponimanija adaptacii cheloveka $v$ otechestvennyh psihologicheskih issledovanijah [Analysis of the understanding of human adaptation in domestic psychological research]. Moscow : Gumanitarnyj vektor [in Russian].

15. Rean, A.A., Konovalov I.A. (2020). Indicators of Parent-Child Relationships in the Context of Various Socio-Demographic Parameters. Integratsiya obrazovaniya. Integration of Education, 24(3), 433-452. https://doi.org/10.15507/1991-9468.100.024.202003.433-452 
16. Sannikova, O., Sannikov, O., \& Husak, L. (2020). Features of deciveness in individuals with different emotional disposition. Georgian Med News, 301, 136-142. Retrieved from https://pubmed.ncbi.nlm.nih.gov/32535578/

17. Seitova, A., Belov, G., Muratov, Z., Murzalieva, A., Abdullaeva, Z., Zhanbaeva, A., et al. (2021). Physiological, Anatomical, Psychological and Cultural-Ethnic Aspects of Indian Students Adaptation during Study in Kyrgyzstan Medical Universities. Open Journal of Medical Psychology, 10(1). https://DOI.org/10.4236/ojmp.2021.101001

\title{
ПРОЕКТИВНИЙ ПІДХІД ДО ВИВЧЕННЯ СОЦІАЛЬНОЇ АДАПТИВНОСТІ Юлія Мадінова \\ кандидат психологічних наук, старший викладач кафедри графічного дизайну \\ Київський національний університет культури і мистецтв \\ 01133, Україна, м. Київ, вул. Коновальця, 36 \\ madinova@gmail.com, https://orcid.org/0000-0003-4899-8378
}

\begin{abstract}
Анотація
Meта: статтю присвячено теоретичному вивченню та обгрунтуванню існування соціальної адаптивності як властивості особистості, iii зв'язку 3 адаптацією і дезадаптацією, іiі дослідженню з позицій цілісного підходу в психології, а також емпіричного пошуку способів швидкого розпізнавання зниження адаптивних можливостей молодого організму та психіки. Завдання: 1) теоретично вивчити підходи до розуміння соціальної адаптивності як властивості особистості, їі зв'язку з адаптацією та дезадаптацію; 2) дослідити погляди на адаптивність в парадигмі цілісності; 3) емірично встановити варіанти дослідження адаптивності за допомогою проективної методики. Методи: застосовано теоретичні методи, аналіз середніх якісних показників, кореляційний аналіз - кількісний i якісний аналіз показників адаптивності та маркерів проективної методики. Результати: проведено теоретичний аналіз підходів до розгляду соціальної адаптивності особистості, його зв'язків із адаптацією i дезадаптацію. Як діагностичний засіб, розглянуто проективні методи діагностики, які дозволяють швидко визначити рівень та показники соціальної адаптивності студента першого курсу. Вивчено середні значення загальної соціальної адаптивності й підтверджено їх кореляційні зв'язки 3 іншими маркерами розладів адаптації. Проведено кількісний і якісний аналіз між показниками адаптивності та проективними маркерами. За підсумками нами побудована модель 3 п’ятнадцяти факторів. Це дослідження виявило, що переважання деяких яскравих кольорів у малюнках сприяє підвищенню загальної адаптації, орієнтації в соціумі та зниженню депресії, а також підвищенню емоційності. Наявність монохромних кольорів показала на зростання емоційності й погіршення самопочуття. Якщо людина застосовує в малюнках штриховку, це підтверджує зниження в неї ригідності. Деякі композиційні фігури вказують на підвищення загальної адаптації й точності орієнтації в соціальних очікуваннях. Наявність таких композиційних принципів, як центр, ритм i пропорції в малюнках свідчать про зростання загальної адаптації та задоволеності, зниження дезадаптації та депресії. Висновки: за результатами дослідження виявлено роль соціальної адаптивності молодої людини, досліджено за допомогою теоретичних методів феномен адаптивності, практично проведено експеримент із використанням проективної методики.
\end{abstract}

Ключові слова: адаптація, дезадаптація, проективна методика, геометрична композиція, соціальна адаптивність. 